\title{
Correction to: A Markov Model to Estimate Mortality Due to HIV/AIDS Using Viral Load Levels-Based States and CD4 Cell Counts: A Principal Component Analysis Approach
}

\author{
Claris Shoko (1) $\cdot$ Delson Chikobvu $\cdot$ Pascal O. Bessong
}

Published online: December 6, 2018

(c) The Author(s) 2018

Correction to: Infect Dis Ther (2018) 7:457-471

https://doi.org/10.1007/s40121-018-0217-y

In the original publication, the following text was missing from the beginning of the Methods section in the main text "This study uses similar methods to those previously published". The missing reference for these methods is:

Chikobvu D, Shoko C. A Markov Model to estimate Mortality due to HIV/AIDS using CD4 cell counts based states and viral load: a principal component analysis approach. Biomed Res 2018;29(15):3090-3098.

Open Access. This article is distributed under the terms of the Creative Commons Attribution-NonCommercial 4.0 International License (http://creativecommons.org/licenses/ by-nc/4.0/), which permits any noncommercial use, distribution, and reproduction in any medium, provided you give appropriate credit to the original author(s) and the source, provide a link to the Creative Commons license, and indicate if changes were made.

The original article can be found online at https://doi. org/10.1007/s40121-018-0217-y.

C. Shoko $(\square) \cdot$ D. Chikobvu

Department of Mathematical Statistics and Actuarial Sciences, University of the Free State, Bloemfontein, South Africa

e-mail: claris.shoko@gmail.com

P. O. Bessong

Department of Microbiology, University of Venda,

Thohoyandou, South Africa 